\section{THE PROXEMIC STUDY OF DWELLING: A CASE STUDY OF TRADITIONAL THAI HOUSES AT BAN KHLONG LAMSALI ${ }^{1}$}

\section{Waricha Wongphyat ${ }^{2}$}

\section{Introduction}

"Dwelling", as the heart of our existence, implies the establishment of a meaningful relationship between human and a given environment. In this respect, the private dwelling, the house, is a privileged entity for a phenomenological study of the intimate value of the lived space. Created from the inhabitants' experience accumulated through time, the lived space, or the existential space, not merely reveals the "here of life" of a dwelling place ${ }^{3}$ but also reflects the "microcultural pattern" of a society as a whole. ${ }^{4}$

\footnotetext{
1 This paper is a part of thesis in Master of Architecture, under the supervision of Assoc. Prof. Tipsuda Patumanon and Assoc. Prof. Lersom Sathapitanonda, Department of Architecture, Faculty of Architecture, Chulalongkorn University and was granted by the H.M. King Rama IX the $72^{\text {nd }}$ Anniversary Scholarship.

2 Ph.D. candidate, Department of Architecture, Graduate School of Engineering, The University of Tokyo, Japan.

3 Christian Norberg-Schulz, Architecture: Presence, Language, Place (Milan: Skira, 2000), p. 12.

4 Edward T. Hall, The Hidden Dimension (Garden City: Anchor Press, 1969), pp. 3, 163.
}

Sadly, with the rapid growth of modernization and globalization, such characteristics of the traditional Thai dwelling, or ruan thai, one which originated from the specific natural settings, e.g. climate, topography, technology, resources, and has been rooted in the matriarchal society-the multidimensional culture, has been gradually disappearing from the scene of our society nowadays.

This study is an attempt to examine the way the dwellers use space in ruan thai within this ever-shifting context. The study specifically pays attention to the sufficient way of life that reveals an intimate relationship with the worthwhile use of space and the respectful use of place. With phenomenology and architectural psychology as its background, the in-depth exploration takes the form of a case study - the traditional Thai houses at Ban Khlong Lamsali, from which the dwellers' way of life and their dwellings would be explicated.

Beginning with the study of the families' way of life, which provides an understanding of the relationship between people and place, followed by a study of the way the dwellers use space and time, or the proxemics, this study focuses on not only the physical but also the psychological dimensions of dwelling experience. Its central goal is to synthesize the "spatial qualities" of ruan thai that could be adapted into the present-day Thai dwellings so as to bring about the "quality of life" to those who reside in it. Before stepping into the proxemic study, let us take a brief look at the context-the matriarchal society, and the important concepts - the dwelling, the house, and the proxemics to which it belongs.

\section{Matriarchal society}

Matriarchal society is the society whose members live in harmony with nature as well as with others. Each inhabitant nurtures their "mother nature", the "mother of mankind". 
Similarly, they extend this friendly relationship through their community, establishing a network of a large extended family. These manifest in a very close-knit environment in a small scale - territory, as seen in the traditional Thai agrarian villages.

\section{Dwelling and House}

Given that "to dwell" is to bury the "seed of life", the word "dwelling" reveals not only the spatial, but also the temporal aspects. Thus, the house, as a manifestation of our dwelling experience, does not serve simply as a shed for shade. Rather it embraces the multidimensional aspects from our past, present, and future. In this sense, it can be inferred that our house provides us "a cradle of life", "a lifegiving retreat", "a center of family life", "a museum of life", and "a never-ending life architecture".

\section{Proxemics}

Proxemics is the interrelated observation and theory of human's use of space. Of the proxemic manifestations ${ }^{6}$, the microcultural level is one on which most proxemic observations are made. The proxemic patterns thereby reveal the hidden cultural frames that

${ }^{5}$ Christian Norberg-Schulz, The Concept of Dwelling (New York: Rizzoli International Publications, 1985), pp. 729.

6 Proxemic manifestations consist of infracultural level - the lower organizational level that underlines culture and is rooted in human's biological past; precultural level - the physiological level that is very much in the present; microcultural level - the intimate level that entails how and where belongings are organized and stored. (Hall, 1969 : 101) determine the structure of a given human's perceptual world. ${ }^{7}$ In essence, its goal makes two contributions; on the one hand, to enhance the quality of lived space vis-à-vis the quality of life and, on the other hand, to enrich crosscultural understandings.

\section{The Family Life Stories}

Life and place are inseparable. Life
"has", "finds", and "takes" place.
Place is the concrete manifestation of
the world of life.
Norberg-Schulz, 2000: 28

Ban Khlong Lamsali is one of the Muslim Thai communities that have established their settlements along canals in the suburb, east of Bangkok (Fig. 1-2). Nearby the Lamsali canal, or Khlong Lamsali, is located a group of traditional Thai houses, or Ban, resided by a large extended family; Mariam's family, Kularb's family, and Sani's family. An area of 3 rai (approx. 4,800 sq.m) includes not only thier houses (Fig. 4-6), but also the very rich landscape - a food forest that allows the families to dwell sufficiently and sustainably. Based on the PMS study (Hall 1973) , their $^{8}$ life stories could be unfolded into 7 themes

\section{The Large Extended Family}

As shown in Fig. 3, Mariam's family, Kularb's family, and Sani's family are in fact a large extended family, in which "3 generations" members live together. Unlike the nuclear family often seen in Bangkok Megalopolis, every member here take better care of each other and each of the multigenerational members takes part in building a homely lived space.

\footnotetext{
7 Ibid., pp. 101-102.

8 See 'The vocabulary in culture' in Edward T. Hall, The Silent Language (Garden City: Anchor Press, 1973), pp. 37-57.
} 


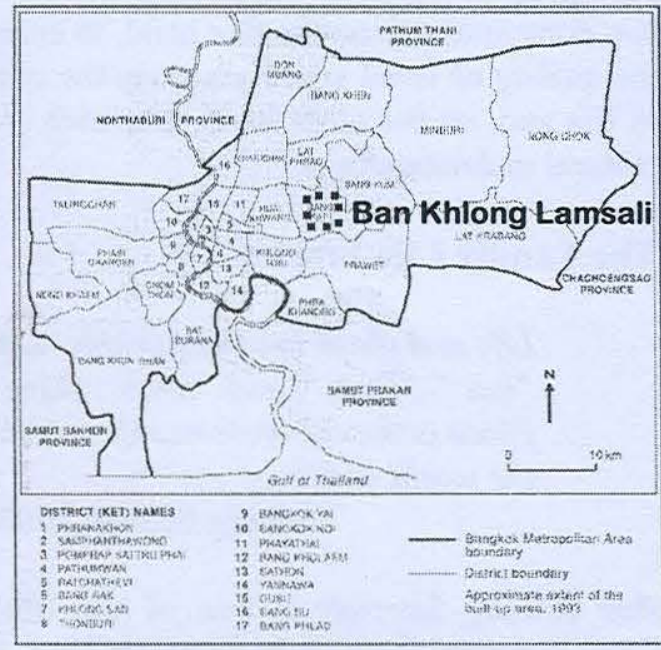

The Bangkok Metropolitan Area [Source: Askew 2002]

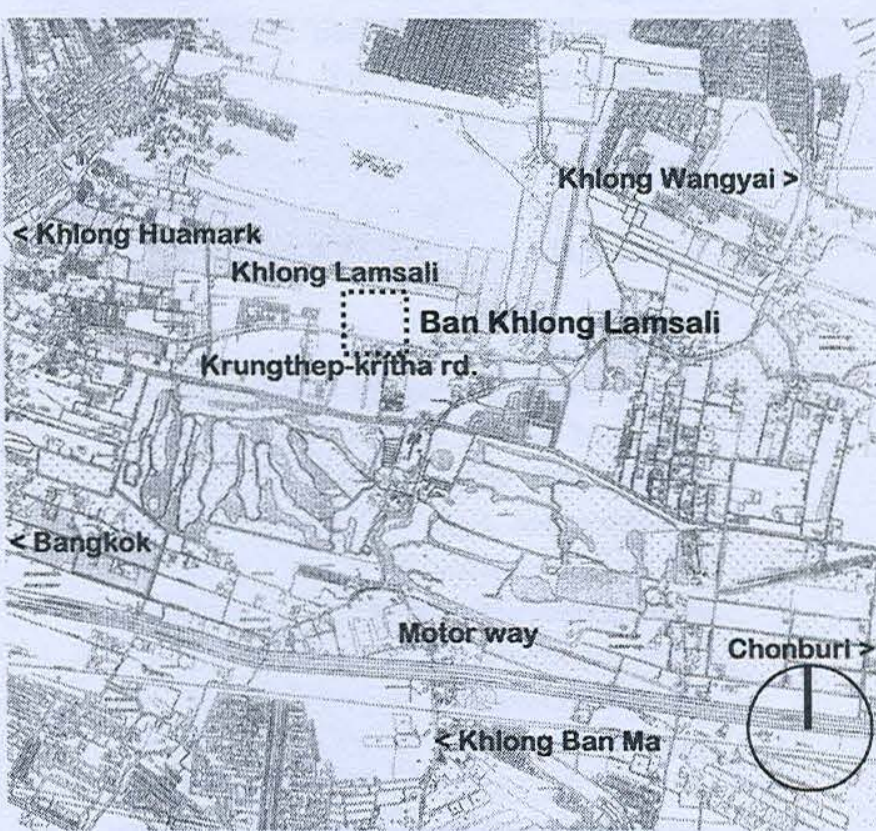

Figures 1-2. Maps showing the location of Ban Khlong Lamsali

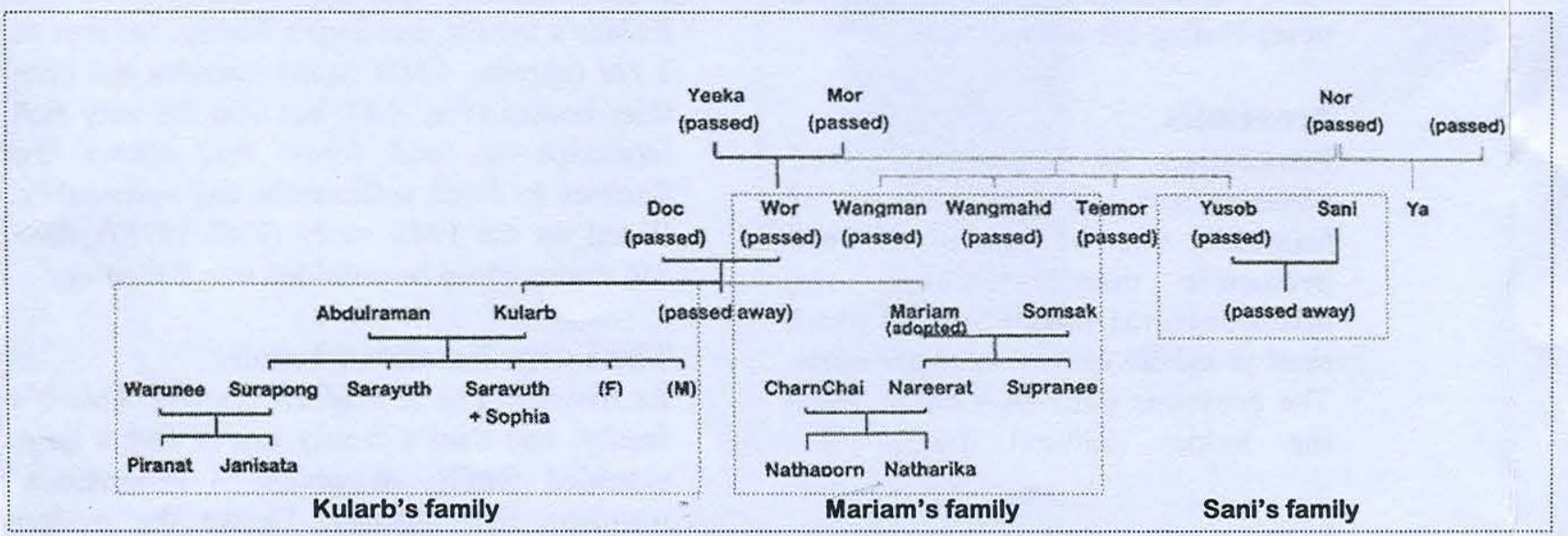

Figure 3. Family relational structure at Ban Khlong Lamsali
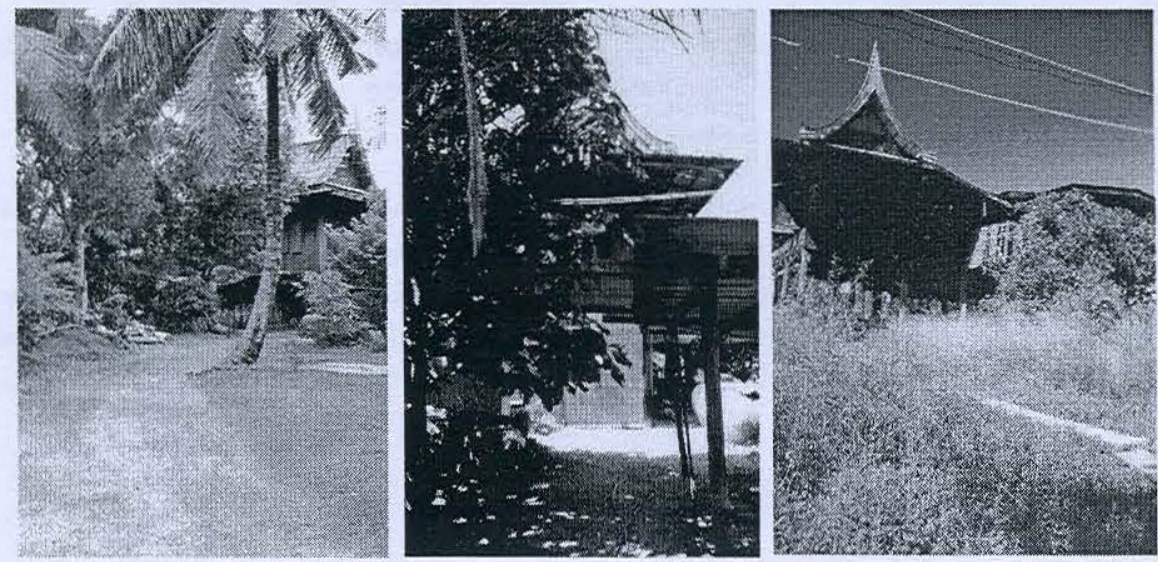

Figures 4-6. Kularb house (left), Mariam house (middle), and Sani house (right) 


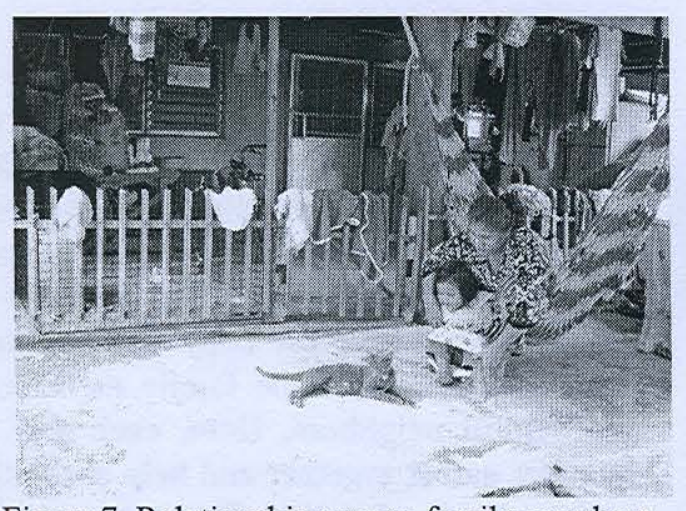

Figure 7. Relationship among family members

\section{The Helpful Neighbors}

Furthermore, the inhabitants here are also the helpful neighbors. They help each other not merely in such daily activities as food sharing, fish catching, but also on special occasions as well. This neighborliness consequently creates unity, solidarity, and the cooperative community of Ban Khlong Lamsali.

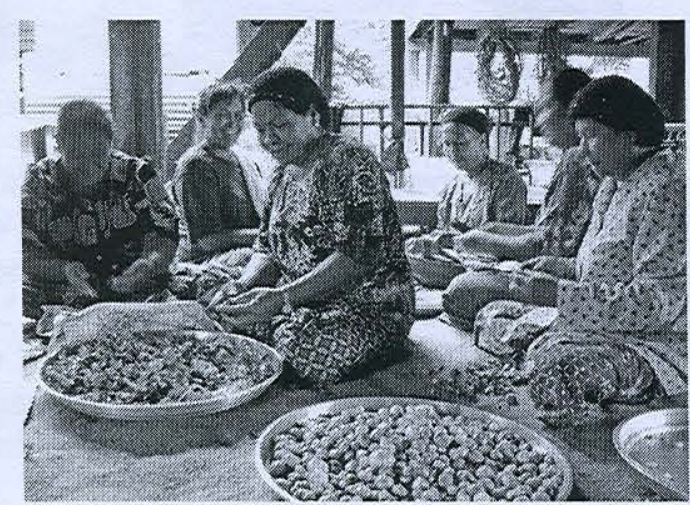

Figure 8. Relationship at Ban Khlong Lamsali: wedding ceremony

\section{The Living Within Nature}

Surrounded by the bountiful environment, the inhabitants live in touch with nature. Here, trees and ponds are the source of life for the families. The residents utilize a wide variety of plants, e.g. bamboo, banana, mango, coconut trees; and fish, e.g. gouramy, catfish, snakehead fish, that are available at hands as important food resources.

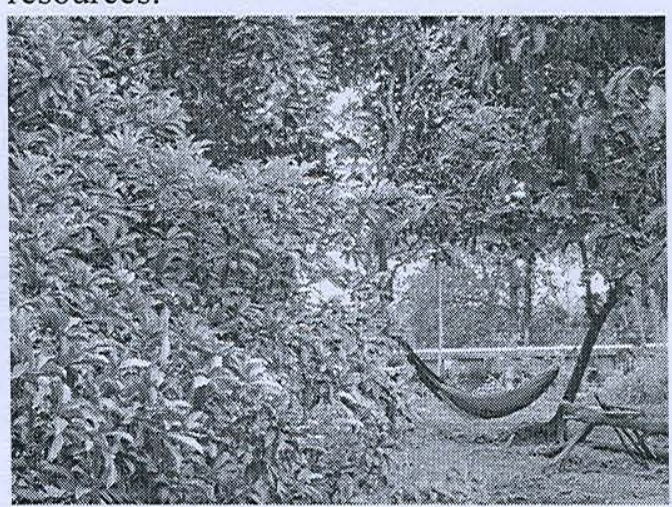

Figure 9. Food forest

\section{The Self-sufficient Life}

The area of approximately $3 \mathrm{rai}$ is comprised of not only the dwellings but also the working quarters. The family subsistence consists mainly of fish, chicken, and cattle breeding, and partly of handicraft. As a rule, men and young members, who at the same time engage in trades, play a vital role in the livestock. Women, after finishing daily work, often gather together to do needlework. Here, each and every member makes a living industriously.

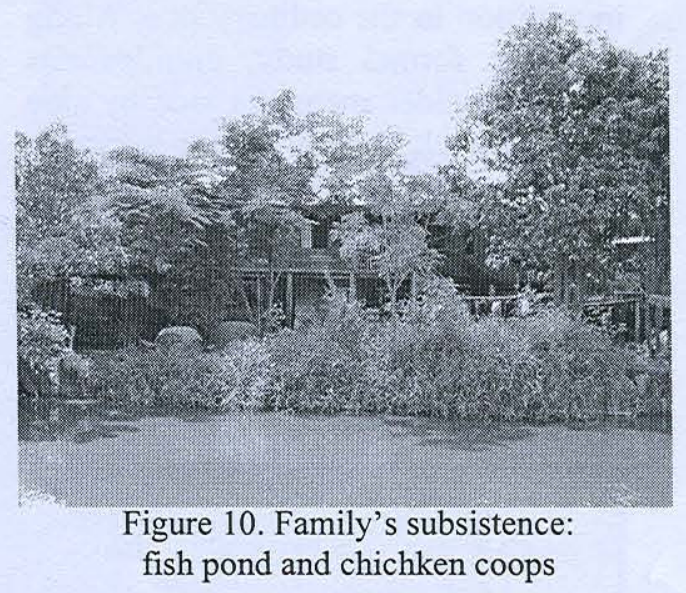

\section{The Playing and Learning}

Likewise, small family members enthusiasticaly explore their "garden of life". The environment that is very rich with a 
variety of plants, flowers, and animal friends is phenomenally a "wonder \& full" land for children. Sadly, such spatial quality, which fosters their learning and creativity, has been lost from many other communities today.

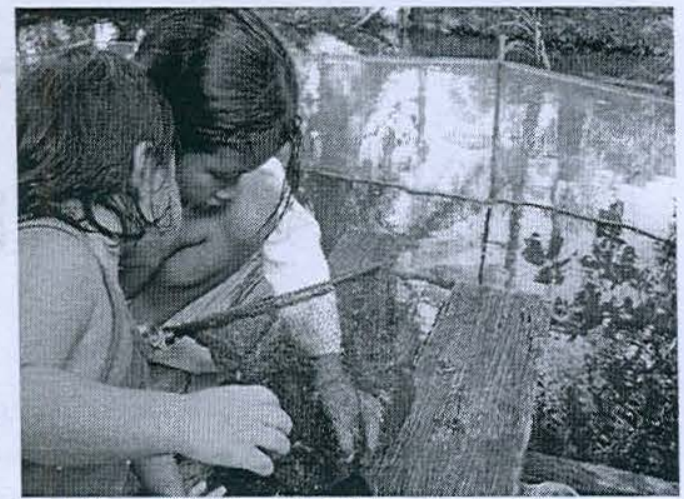

Figure 11. Small children's world

\section{The Faithful Life}

As in Muslim society, the family members never neglect to pay daily reverence to God, "pray" (or lamad). In order to understand the Islamic teaching and act as the moral Muslim, the young also attend religious school in addition to the ordinary one. Along with the formal study, grandparents and other elder members side by side train their children in basic manners. Through such daily practice, the children gradually comprehend the Muslim way of life.

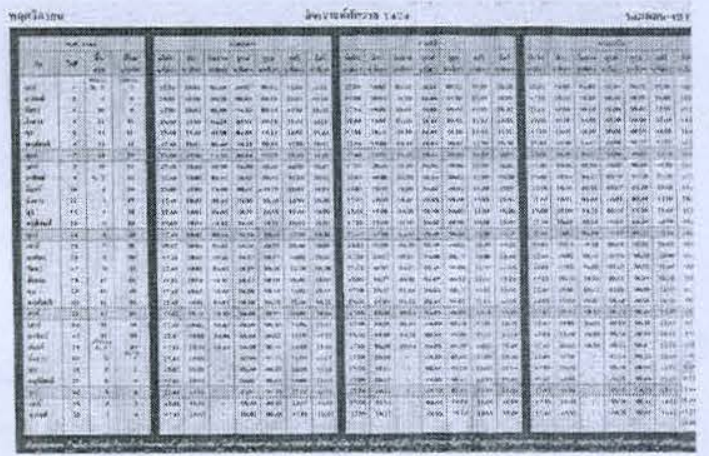

Figure 12. Lunar calendar showing "pray" time

\section{The Festive Life}

In the wider perspective, the communal spirit at Ban Khlong Lamsali manifests itself in the daily experiences as well as the festive occasions such as wedding ceremonies and religious activities. Whether in a special festival or a small simple one, the most vivid scene is the busy, yet cozy and cooperative atmosphere between the family members and the helpful neighbors. Here, each and every member gather together and help each other in various kinds of duties. Through such festive occasions, communal unity is consequently developed.

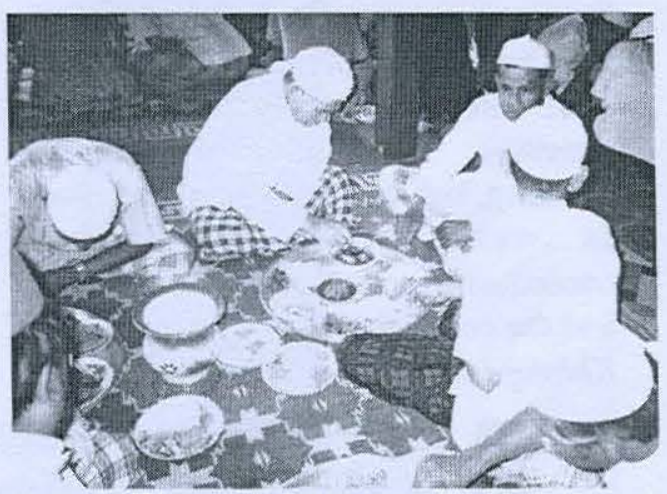

Figure 13. Communal spirit: after-Fast festival

Here and now, the family life stories already paved way to our understanding in the way of life, the relationship between people and their dwelling place at Ban Khlong Lamsali. Hence, in the next step, we will then expound on the way the families' use space, the proxemics, to which the study pays specifically attention.

\section{The Proxemic Study in Dwelling}

In the proxemic study, we will see how the space in each house manifests itself through a series of theme analysis. With phenomenological interpretation, the study will be principally based on the voices of the inhabitants, the oral history, and the sketches of their life situation, ones that give us the in-depth comprehension on the multidimensional aspects of the dwelling place. 


\section{Mariam house}
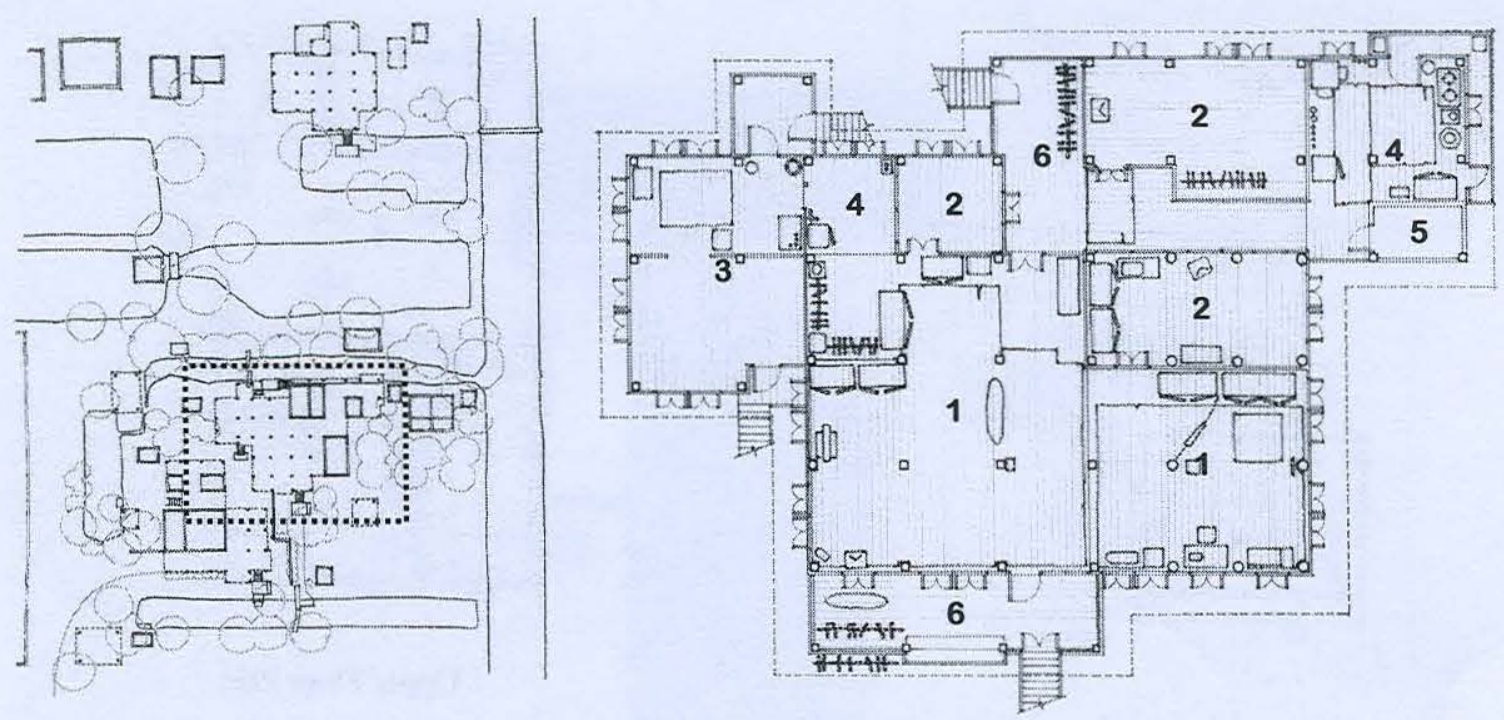

1. hall

Upper Floor Plan

2. bedroom

3. rental room/storage

4. kitchen

5. toilet

6. chaan

7. stair/waterfront

8. taitoon

9. needlework room

10. storage

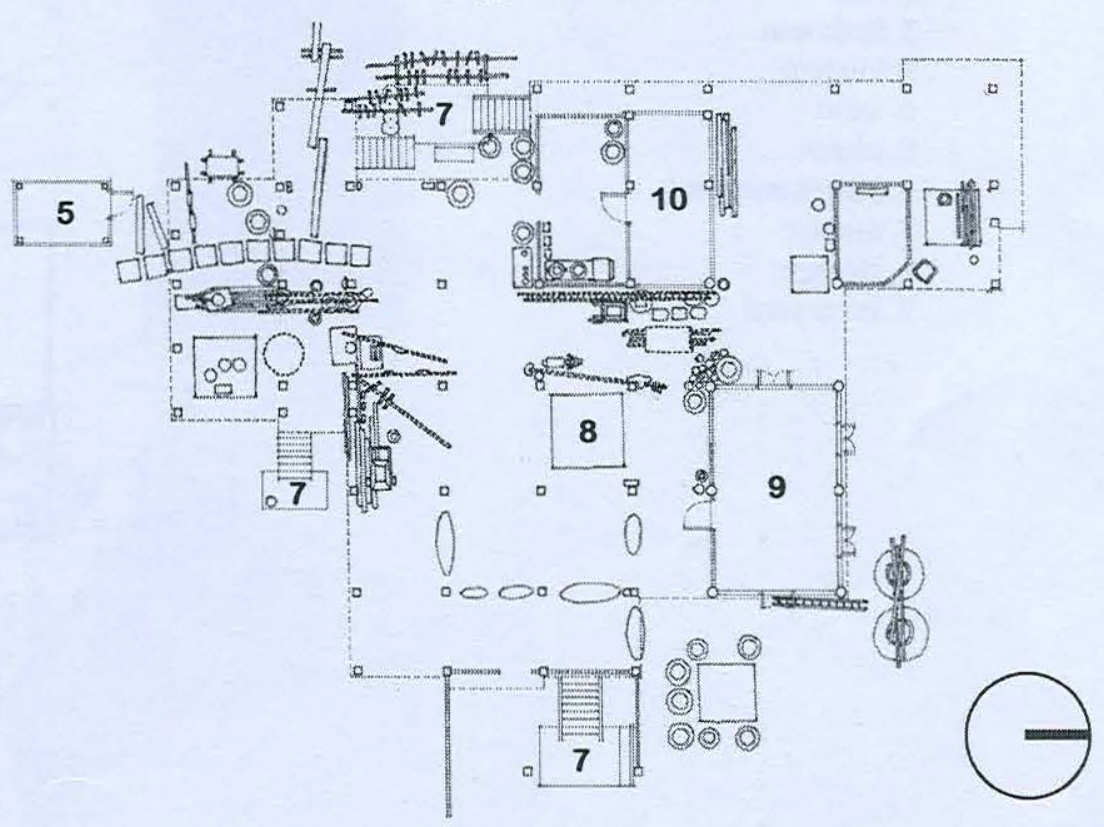

Lower Floor Plan (Taitoon) scale 1: 200

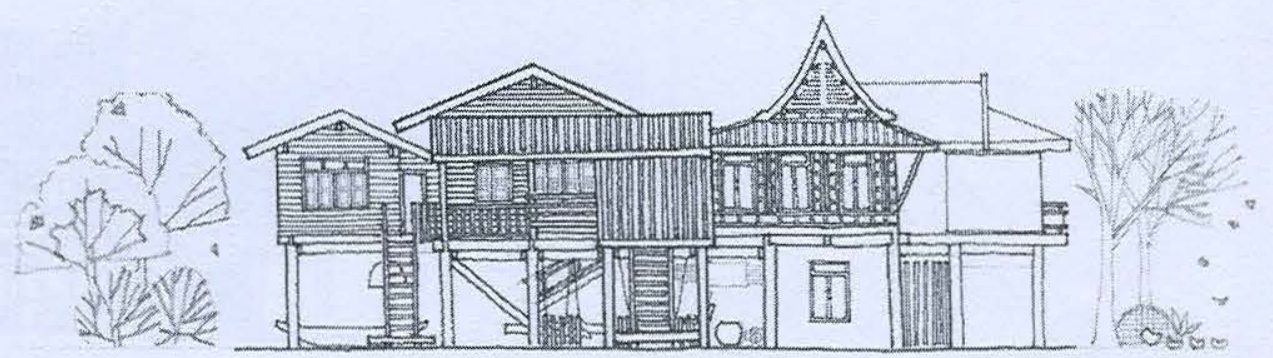

East elevation

Figure 14. Mariam house 


\section{Kularb house}
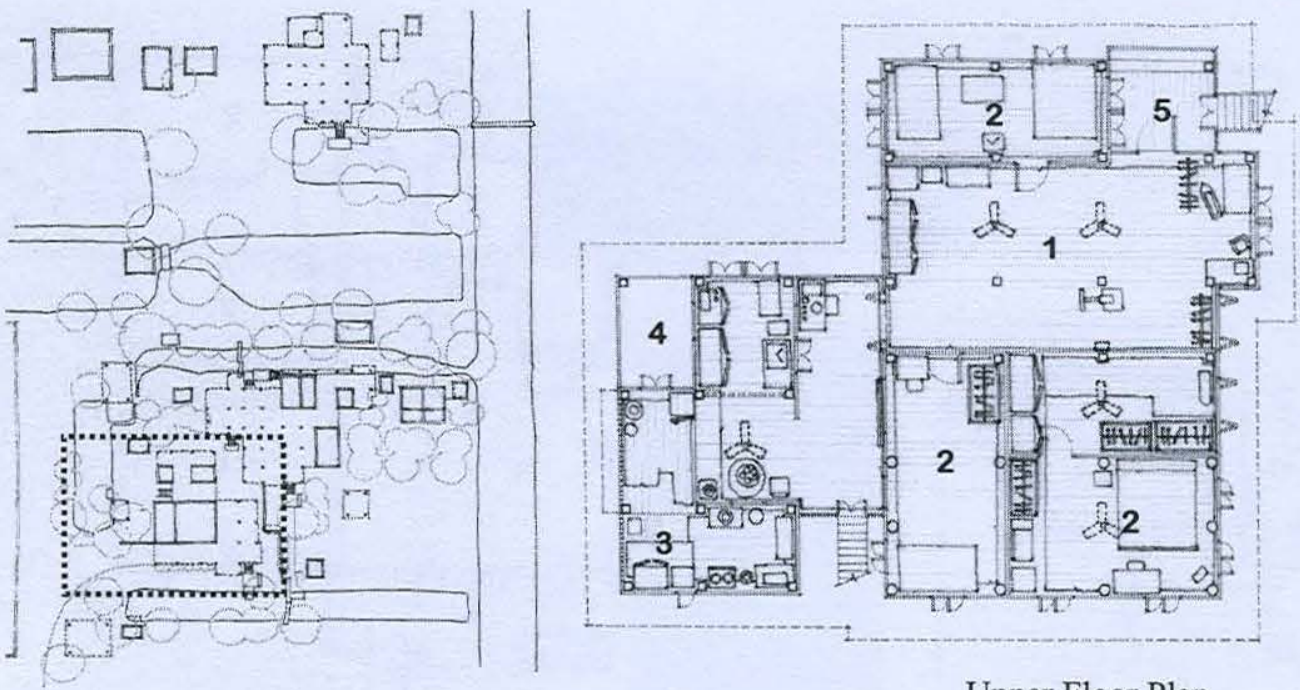

Upper Floor Plan

1. hall

2. bedroom

3. kitchen

4. toilet

5. chaan

6. stair/waterfront

7. taitoon

8. storage

9. front yard

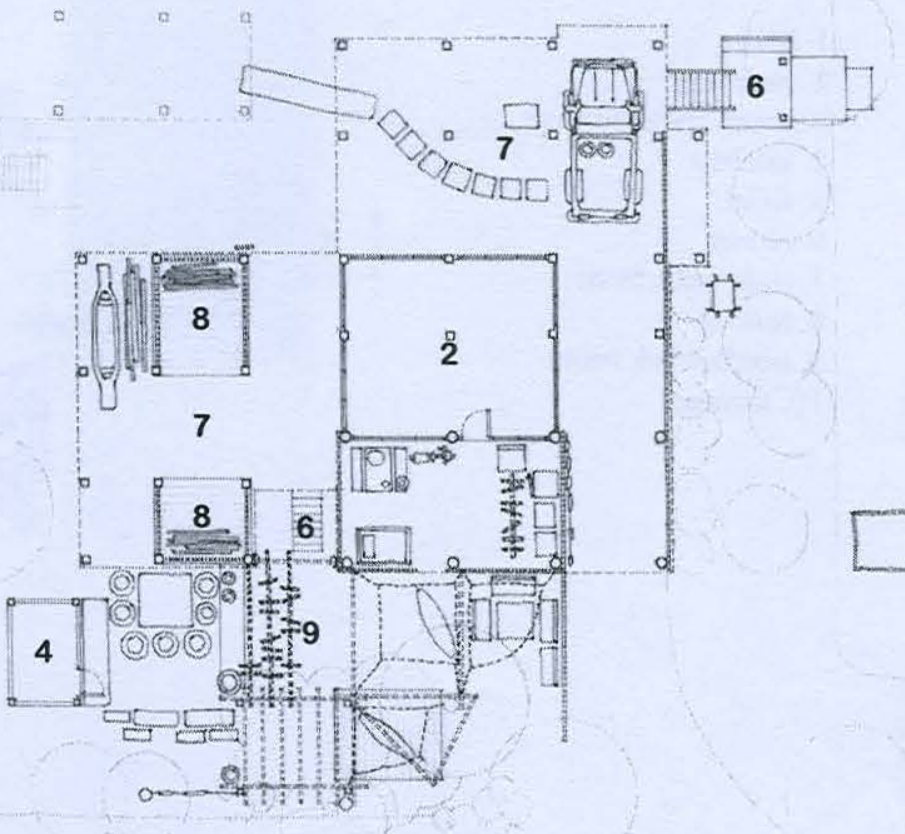

Lower Floor Plan (Taitoon) scale 1: 200

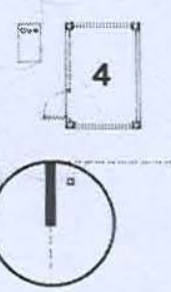

$$
\text { scale 1: } 200
$$

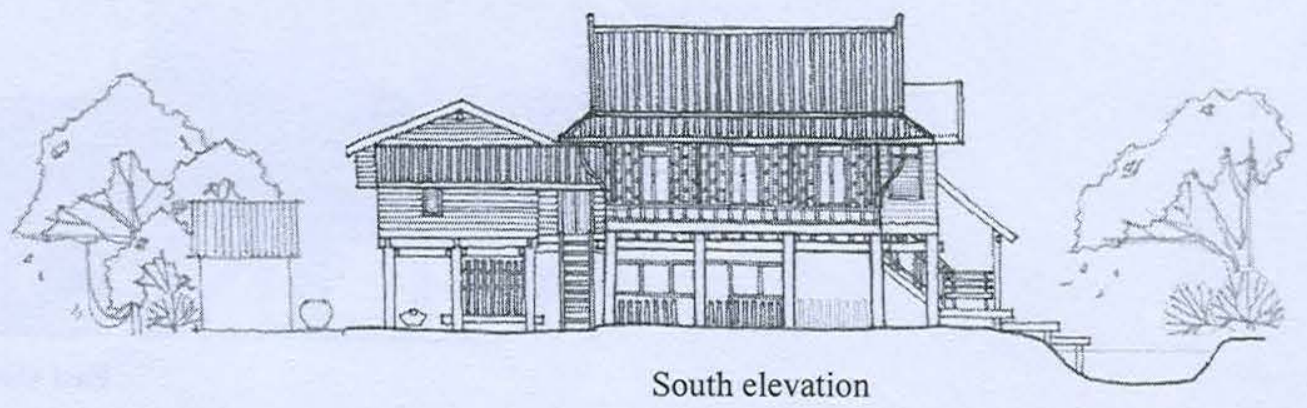

Figure 15. Kularb house 


\section{Sani house}
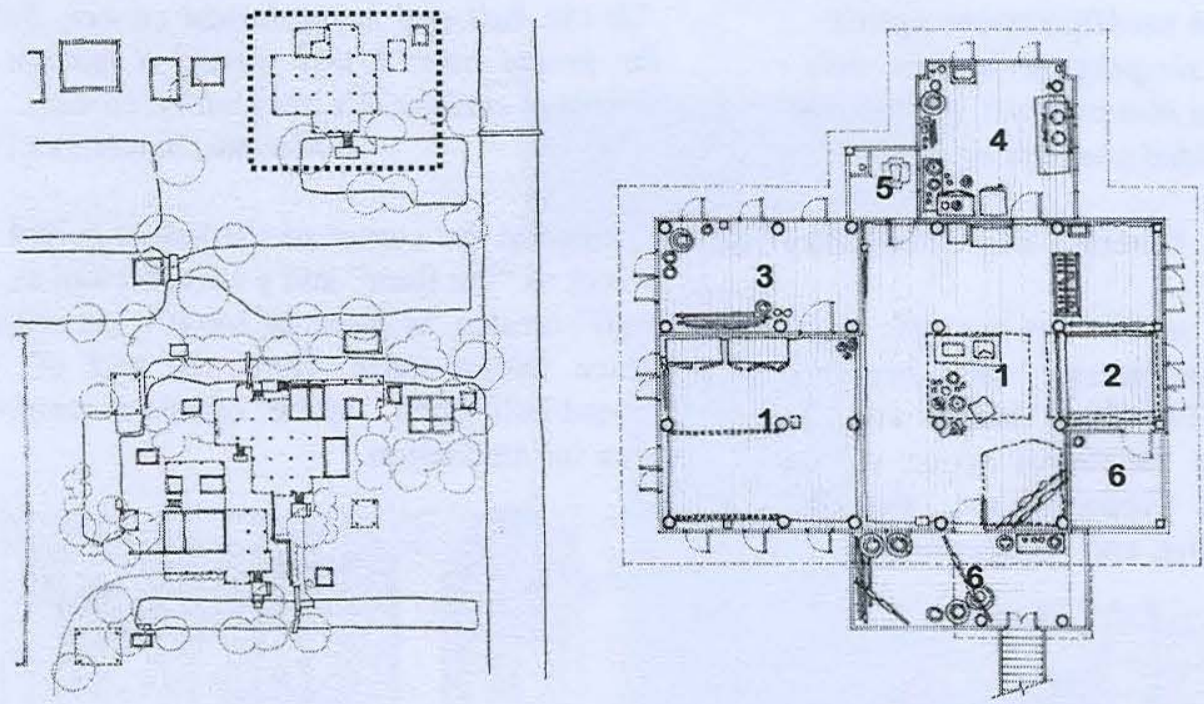

1. hall

2. sleeping area

3. bedroom/storage

4. kitchen

5. toilet

6. chaan

7. stair/waterfront

8. taitoon

9. water tank

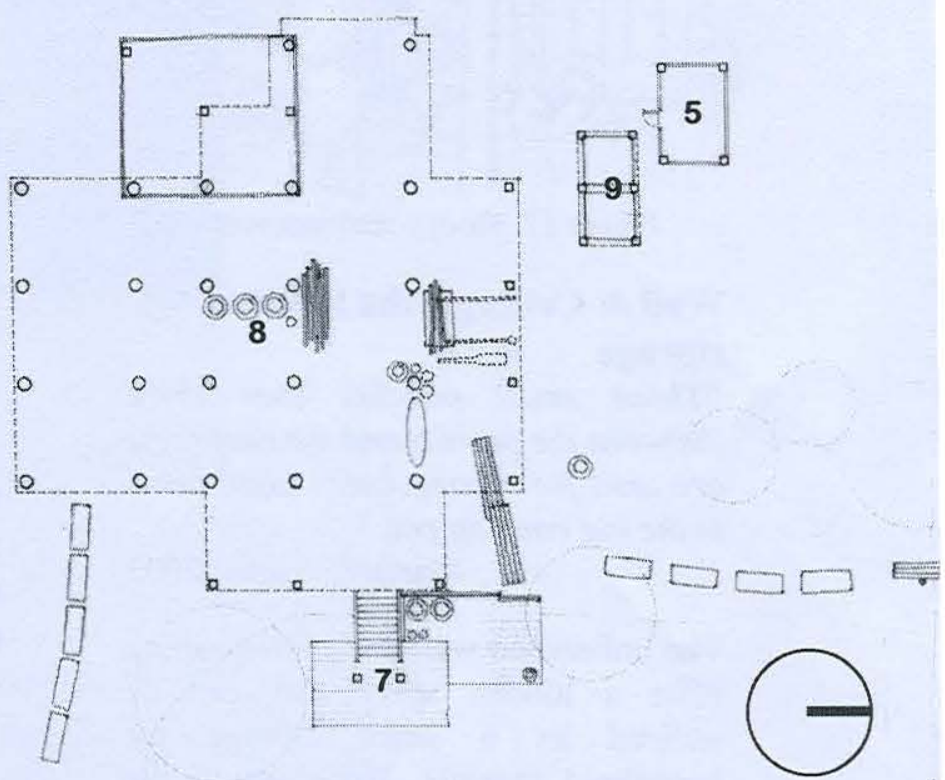

Lower Floor Plan (Taitoon) scale 1: 200

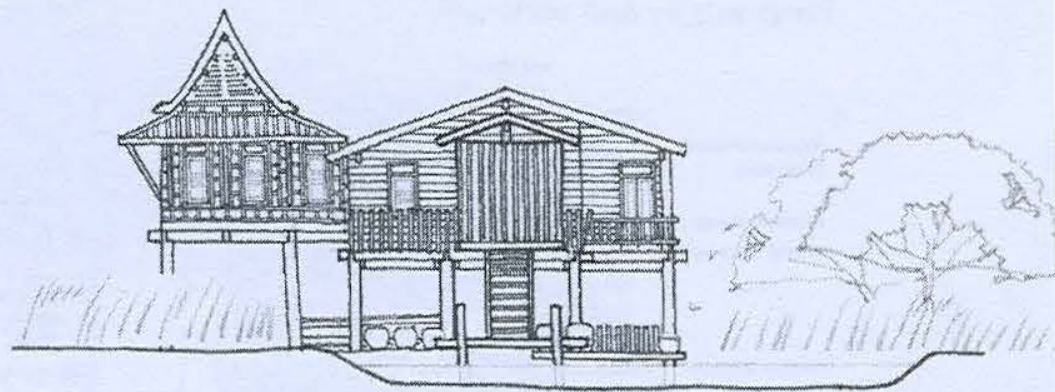

East elevation

Figure 16. Sani house 


\section{Mariam house}

Floor - the multipurpose space "We prefer sleeping on the floor with a quilt and a mosquito net, as they can be easily folded and kept at a corner of the house."

Nareerat, September 2003

With the small amount of fixed furniture, the interior space becomes flexible. The floor itself acts as furniture- $\mathrm{a}$ functional space served for various purposes, e.g. sleeping, resting, dining, and socializing.

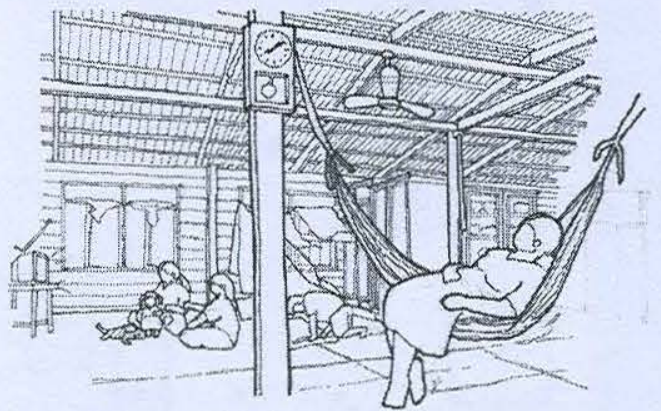

Figure 17. Floor - multipurpose space

\section{Wall \& Ceiling - the hidden storage}

"Those small paddles over there (between the purlins and the roof tiles) are used for mixing curry ingredients in the big cooking pot."

Mariam, August 2003

The unfinished wall and roof structure offer a hidden space that can be utilized as a small storage for household utensils. As a result, the floor, the wall, and the ceiling together create a multifunctional space both horizontally and vertically.

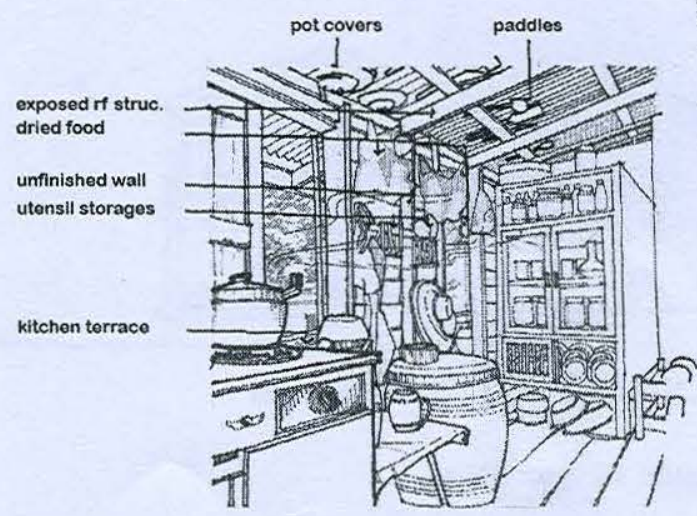

Figure 18. Wall \& Ceiling - kitchen utensils storage

\section{Floor \& Wall - A Meditation Corner}

"At the hall end is my lamad corner. Before the lamad time, I will spread a mat on the floor and enclose this area with a curtain..."

Mariam, November 2003

Located at the corner of the hall, a carpet that serves as "the floor" and a curtain cloth as "the wall" creates " $a$ germ of room"- an intimate space within space. Here, the sort of "half closed/half open" space offers a temporary area for meditation.

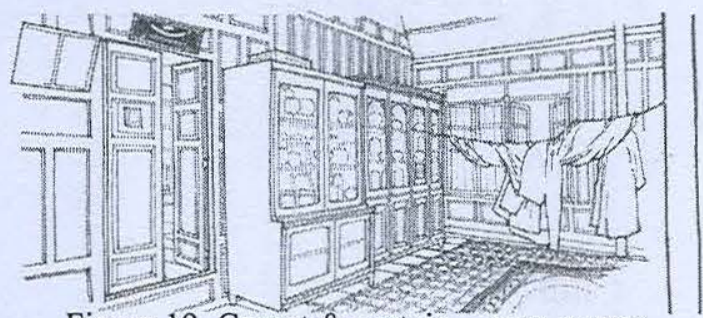

Figure 19. Carpet \& curtain - pray corner

\section{Central hall - the corners of life within the center of life}

"Every night, we often gather and watch TV together. My favorite corner is this hammock. From here, I can talk with them and do needlework at the same time."

Mariam, June 2003

The open interior with small amount of furniture brings the hall a center of family life, while the hammock nearby provides a corner of life for the inhabitants. And so, the hall plays a dual role-a center of life vis-à-vis a corner of life, simultaneously.

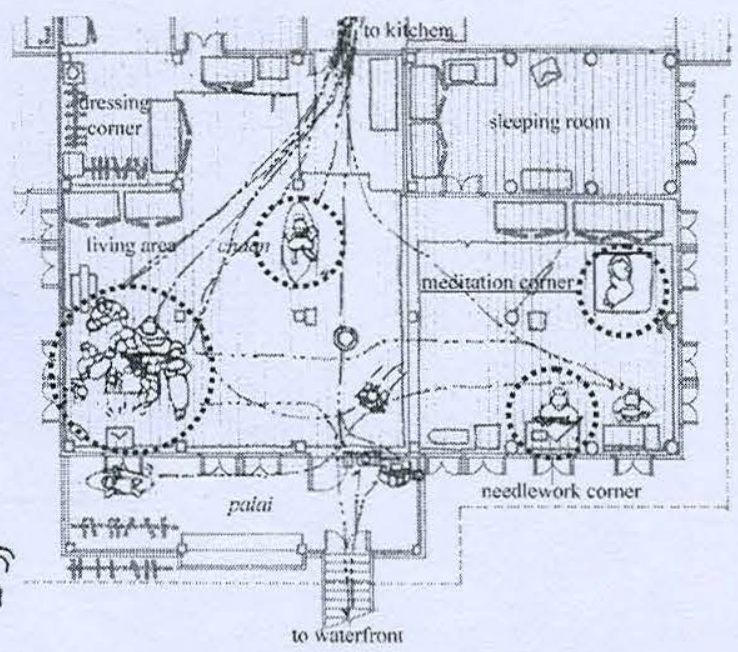

Figure 20. Central hall - corners of life 
Chaan - the locus of family's life "My grandchildren love this chaan. Because, unlike the inside hall, it is bright and breezy. From here, they can talk to their neighbors."

Mariam, October 2003

The characteristic of "half inside/half outside" makes the chaan "an extension of interior space" serving for various uses, e.g. taking rest, doing hobby, greeting guests, drying clothes. Here, the chaan becomes a center of life, especially during daytime when the house is hot and ill-ventilated.

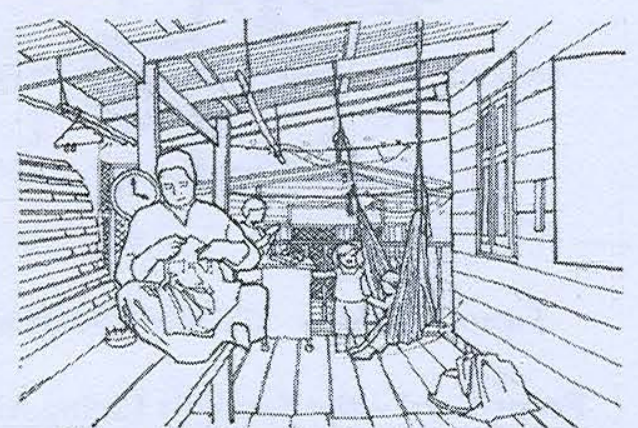

Figure 21. Chaan - family living area

\section{Open stairway - the multistory} space

"I love this stairway and sit here. It is breezy."

Natharika, September 2003

The airy stairway with open risers and steps made up of wood is a favorite place for family members. To children, the various wooden steps can be transformed into tables, chairs, or even stages. In addition, the stairway is a meeting place for the family and the neighbors. It is a small node where countless life stories take place.

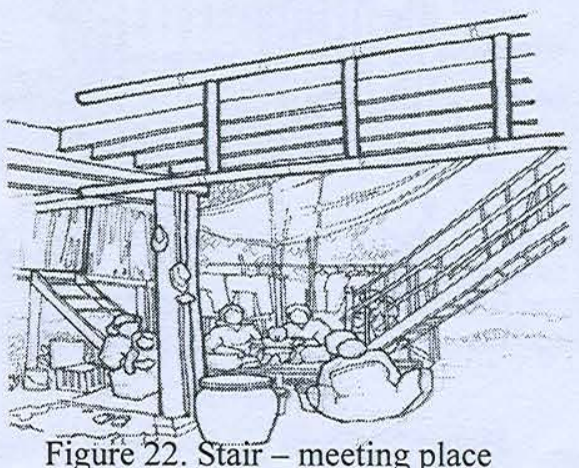

Figure 22. Stair-meeting place
Open taitoon - the node of communal life

"Taitoon at my sister's house is quite low with most of the area partitioned off. So her family often comes and gathers around here."

Mariam, December 2003

Several hammocks encircling the taitoon create a sociopetal space- a living area for daily interactions. Besides, it can be changed into a large kitchen during festive occasions. Here, the open taitoon is manifestly a space of loving communal life.

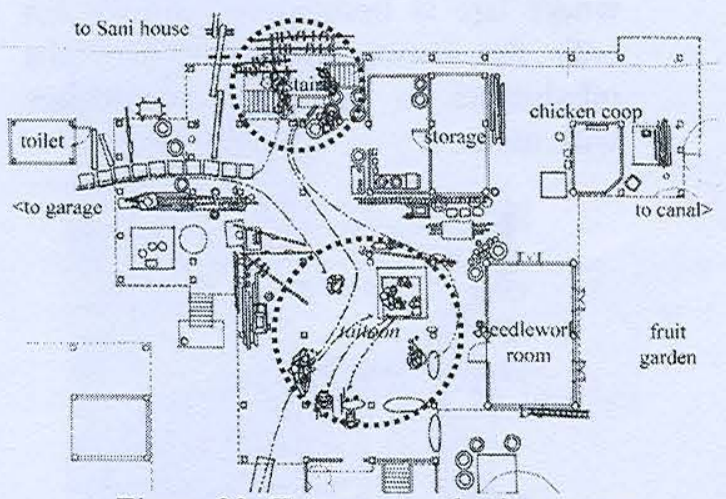

Figure 23. Taitoon - gathering space

\section{Hammock - the nest of life}

"I love taking rest in the hammock and talking with my family. It is my pleasant time."

Mariam, June 2003

With its special quality that gives the inhabitant small protective warmth, the hammock becomes "a cradle of life". At times, it is a place for resting; at others becoming a forum for socializing. Due to its flexible ability to be transformed into any shape and swung in any direction, the hammock is thereby a favorite place for a member of all generations.

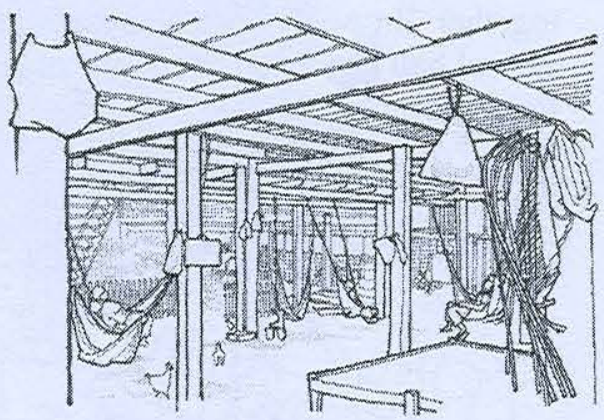

Figure 24. Hammock -resting space 


\section{Kularb House}

\section{Breathable Floor - Breathable Wall}

"This sliding wall can open throughout the column bay. We close it at night and open in the morning for natural light and ventilation."

Kularb, October 2003

The sliding lath wall and the airy wooden floor with a raised step bring natural light and breeze to the interior. The space that can go out and come in where life is being lived allows not only the house itself, but also the inhabitants to breath in accordance with nature.

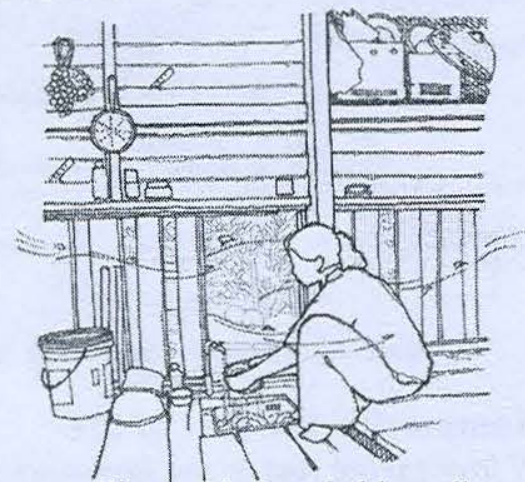

Figure 25. Breathable wall

\section{Central Hall - the Space of Loving Togetherness}

"In the evening, we gather around. Here, we eat, talk and watch TV together."

Piranat, September 2003

With the breathable floor and walls, the central hall welcomes communal life to take place. Here, the family members sit, talk, and have meal together. In such special events, the central hall can be adapted into an area for greeting guests.

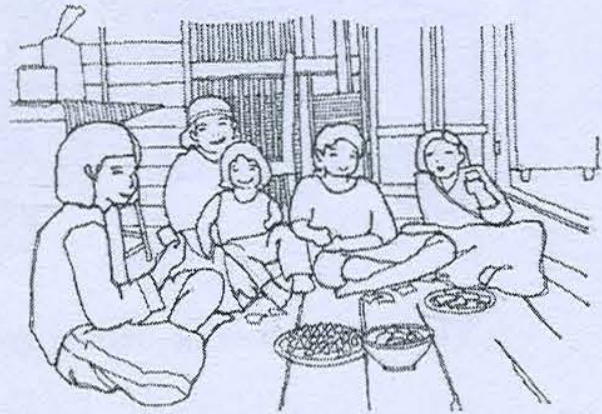

Figure 26. Central hall-gathering space

\section{Chaan - the Small Children's World}

"I love to play here, because I can close the door. If I play inside, run around, and make loud noise, my grandmother will blame me."

Piranat, September 2003

The sort of "half-open and half-closed" character of the chaan provides a small hidden territory for children. In their own world, younger members of the family explore a variety of actions far bevond their threshold.

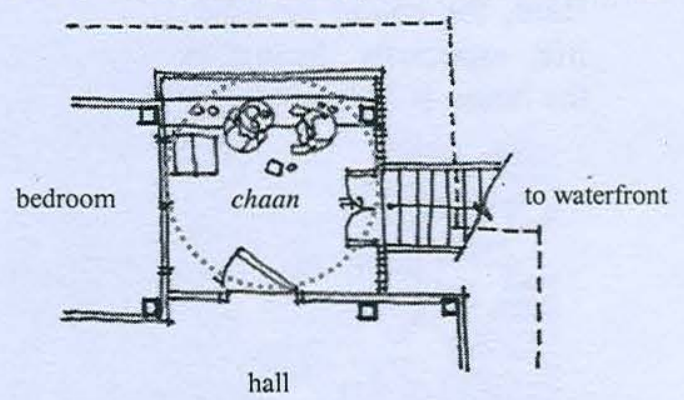

Figure 27. Chaan - Children favorite area

\section{Front Yard - the Family's Living Area}

"Most of the time, weekdays or weekends, we like to stay in the front yard. It is breezy."

Warunee, December 2003

Surrounded by water ponds and shielded by tree shades, the front yard welcomes not only the family but also the passer-by to gather around. The enticing spatial quality; fresh breezy air, the sweet smell of flowers, the song of garden birds, allows the inhabitants to dwell peacefully and poetically.

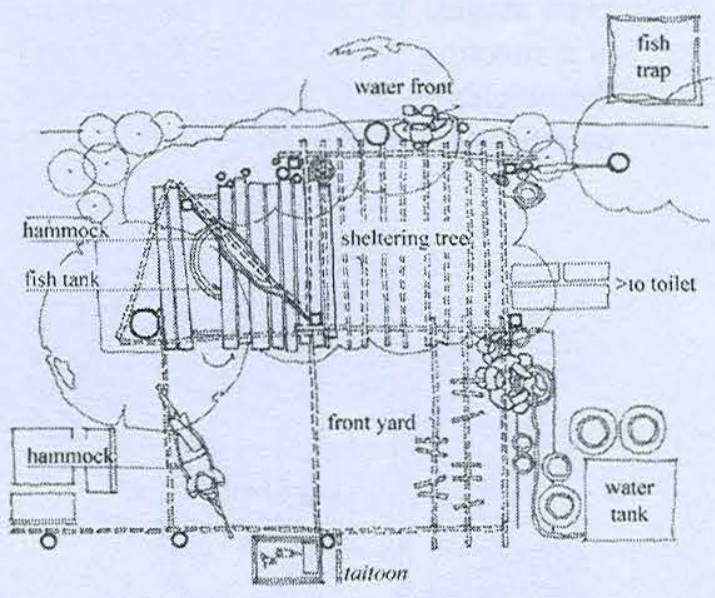

Figure 28. Front yard - family living area 


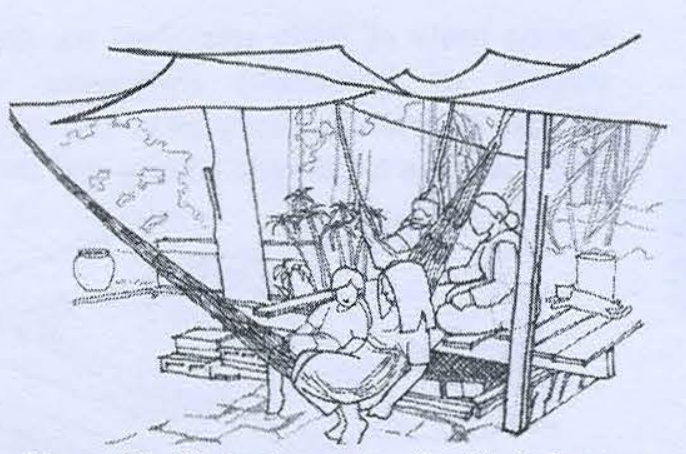

Figure 29. Sheltering tree - family living area

\section{Waterfront - the outdoor bathing area}

"Women take a bath here, just across the front stair, because it's convenient. As for men, they often use the waterfront at the entrance way."

Kularb, August 2003

As a source of delightful sensation, the waterfronts are used as the family's bathing areas. Surrounded by dense trees, the enclosed waterfront inside the house is reserved for women, while the open, well-ventilated mainly serves waterfront outdoor.

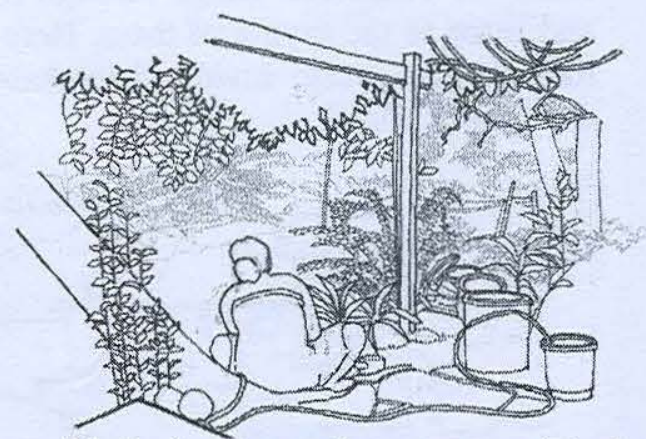

Figure 30. Enclosed waterfront - women's bath area

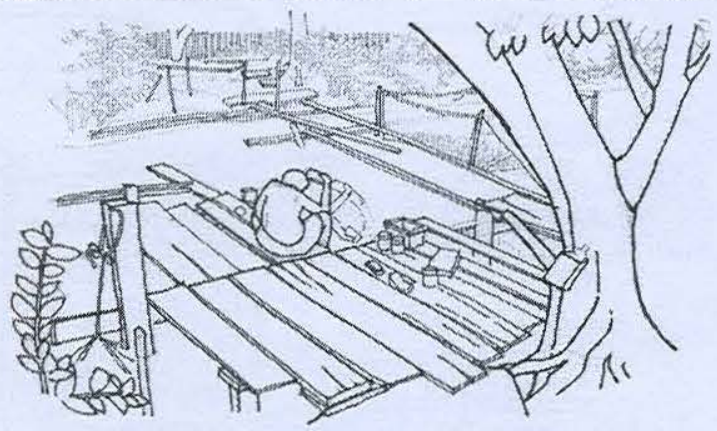

Figure 31. Open waterfront - men's bath area

\section{Breathing - Speaking floor}

"I love to talk to my neighbors. As my house is on the way to the bridge, they often stop by my house at the taitoon and greet me."

Sani, December 2002

Quite similar to Kularb house, the airy wooden floor with a raised step and the walls with low windows bring optimal ventilation to the house. In addition to this, the openness of the floor plays another role. Without a riser between floor levels, the comparatively high step provides a space for the informal interaction between the inhabitants and the neighbors.

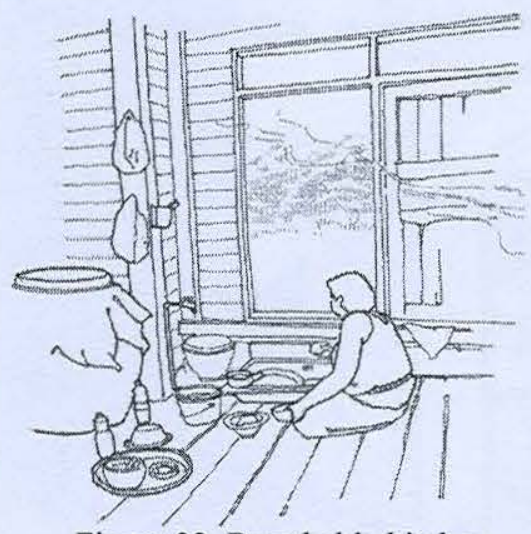

Figure 32. Breathable kitchen

\section{Wall - the Hidden Storage}

"I usually hang lades, pots, onions, garlic on the walls. It is convenient."

Sani, December 2002

As seen in the case of Mariam house, the unfinished walls provide additional spaces for keeping kitchen utensils. This is a method for utilizing such small space with the optimum use.

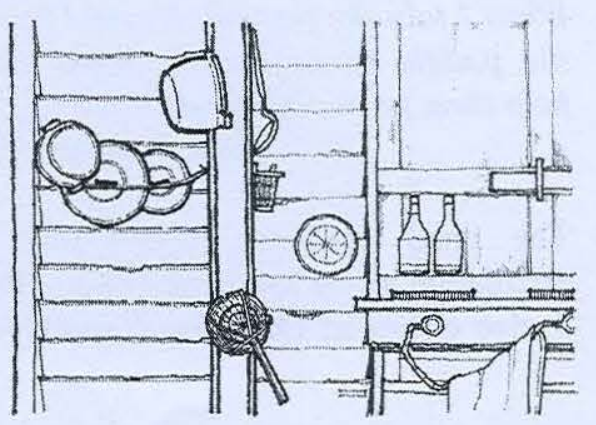

Figure 33. Wall \& post - kitchen utensils storage 


\section{Central Hall - the Corners of Life \\ "The corners I often use are those overhung by the canvases."}

Sani, March 2003

With the use of such space dividers as canvas, curtain, and carpet, the open hall is transformed into the "corners of life". When the canvases serves as ceiling planes, the curtain as wall, and the carpet as (temporary) floor, the areas for living, resting, and meditating are concretely defined. In this "being within", the enveloping intimate space welcomes life to take place.

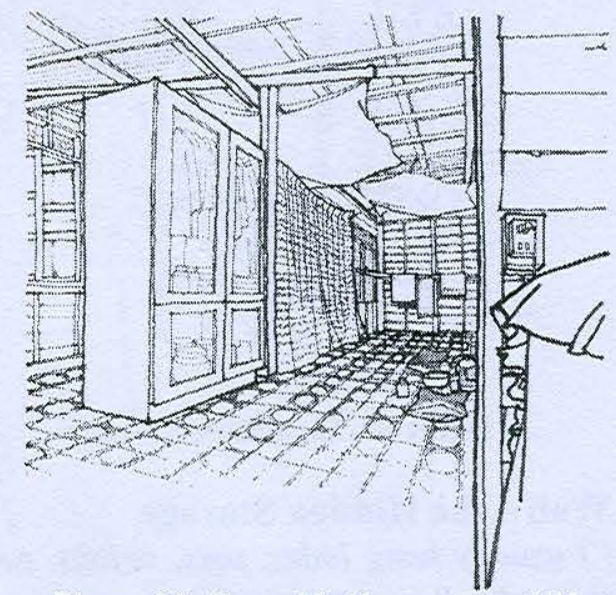

Figure 34. Central hall -corners of life

\section{Open structure - the extensional space}

"As I have no longer used those paddles and fish traps as often as before, I have kept them at the taitoon. When I join the festival, I would bring the paddle to the host's house and help them preparing food."

Sani, August 2003

The open taithoon only allows a circulation space to the neighbors. But it also offers an extensional space for storing tools of daily use. And so, the small amount of household equipment on the ground, people can easily pass through, take a rest, and have a dialogue among one another.

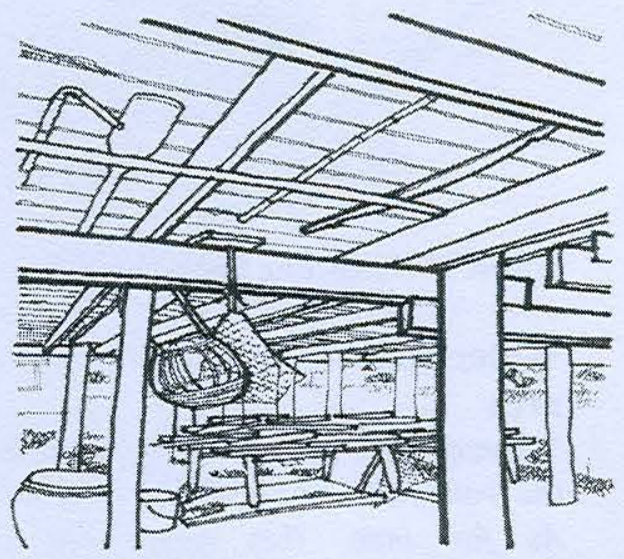

Figure 35. Taithoon - household tools storage

\section{Waterfront+trees - the world of life}

"When this tamarind tree grows, not only it provides a shady ambience, but also welcomes little garden birds to visit my house."

Sani, December 2003

The world of life will become endlessly rich when we could see things through new eyes and listen to the saying of them. Here too, the multisensory world invites the inhabitants to dwell poetically.

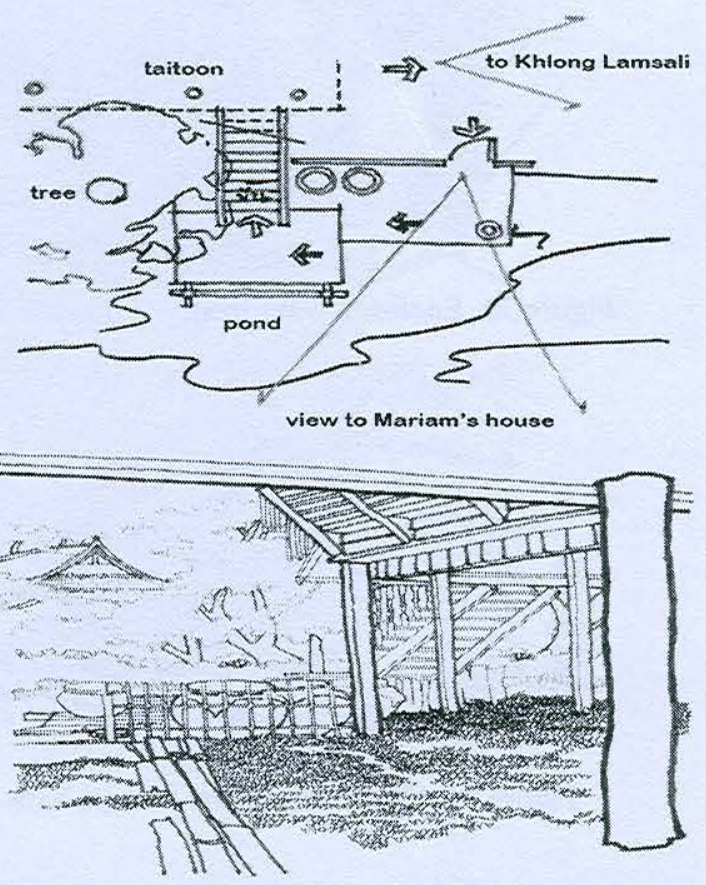

Figures 36-37. Waterfront - multisensory world 


\section{Conclusion:}

Spatial Characteristics in Dwelling Through the proxemic study, several spatial themes emerge. In this final part, the study will interweave together such spatial elements as the multipurpose floor, the breathable wall, the unfinished ceiling, into the overarching themes of the entire lived space. Based on the study of human needs (Fromm 1990) ${ }^{9}$, the multidimensional dwelling space derived from the case study yields 5 spatial qualities-multifunctional space, space in space, dialogical space, multisensory space, and growable space-all of which, as we will see, reveal a glimpse of how these spatial characteristics would be adapted into our present-day dwelling.

\section{Multifunctional space}

Multifunctional space, in more general sense, is the multipurpose space that can be utilized at both the horizontal and the vertical dimensions. And so, as seen in the case of Mariam's chaan and taitoon (Fig. 21, 23), Kularb's front yard (Fig. 28), and central halls of each house (Fig. 17, 26, 34), it serves various uses not only in a dayto-day basis but also in festive life. It is noteworthy that the worthwhile use of space provides a very essence of the living with intensity of ruan thai. Besides, the worthwhile use of space aptly represents the "creativity" of the traditional Thai dwellers as well.

\footnotetext{
9 Human needs consist of relatedness, transcendence or creativity, rootedness, identity, and frame of orientation, see Erich Fromm, The Sane Society (New York: An Owl Books, 1990), pp. 63-66.
}

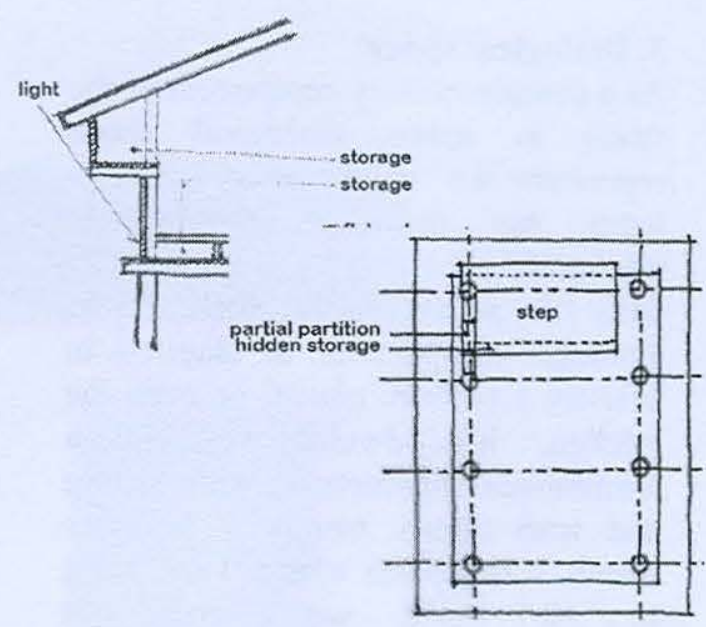

Figures 38-39. The openness of structure with the depth of floor, wall, or ceiling create the multifunctional space that can furnish our (multi-)stories of life

\section{Space in space}

Space in space, in this regard, is the "corner(s) of life". Contrary to the box-like room, it provides a sort of "half-enclosed/halfdisclosed" quality - a space with openings. As this space has no fixed territoriality, it can also be considered a "shared space" - a space without permanent ownership. Its image is manifested in the case of the hammock in Mariam's hall (shared space; temporality, Fig. 20) and in the case of the sheltering tree in Kularb's front yard (shared space; territoriality, Fig. 29). Such small favorite corners, or the intimate space, within space, consequently bring the inhabitants a "sense of identification", while they can still be a part of a larger whole.

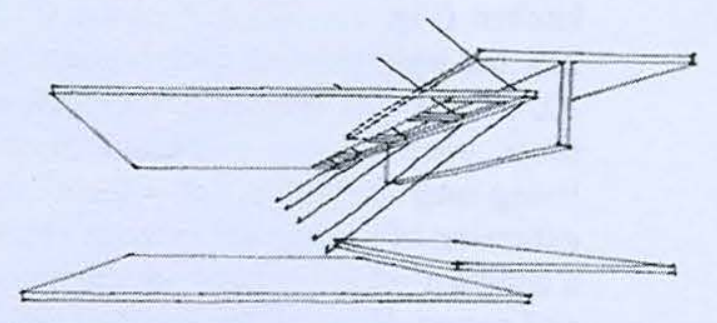

Figure 40. The different volume of space created by a raised floor and/or ceiling with some openings brings about the space in space-the corner of life within the entire space 


\section{Dialogical space}

As a complementary component of the space in space, dialogical space represents the "center of life". It is a locus not only of the family relationship but also of all the tools of daily life, as well as the world of life. Through its openness, as manifest in Mariam's taithun, chaan, or even the kitchen, life dwells well in a harmonious interaction with nature and with family members. In other words, it is a place where 'I am being in the world with others' is determined.

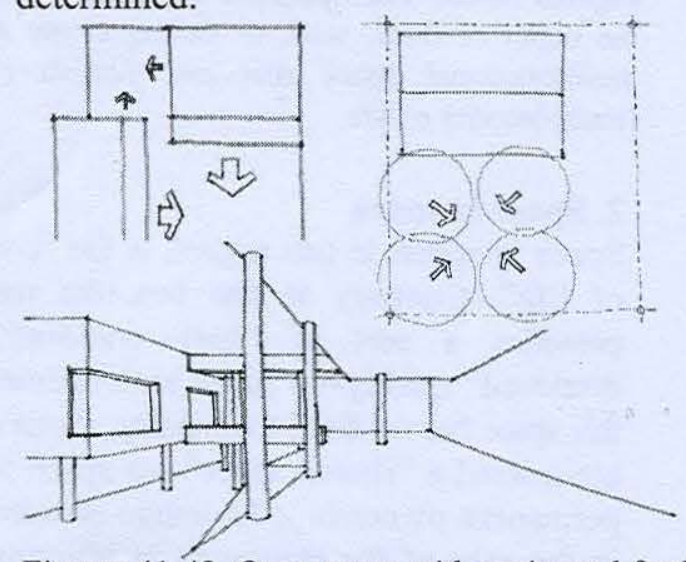

Figures 41-43. Open space with sociopetal feather offers a dialogical space for our dialogical life

\section{Multisensory space}

Aside from the physical aspects of the lived space, the multisensory space offers psycho-poetic dimensions in the dwelling experience. As seen in the kitchen (Fig. 25, 32), the chaan (Fig. 21 ), the waterfront of each house (fig. $30,31,36)$, its spatial quality that at times becomes the extension of the living-interior space, at others the extension of the natural-exterior create a constant interplay between the house and nature. Here, all the sense of sight, smell, hearing, and touch are drawn into a close proximity. Here too, the "frame of orientation" towards the world of life allows life to dwell peacefully
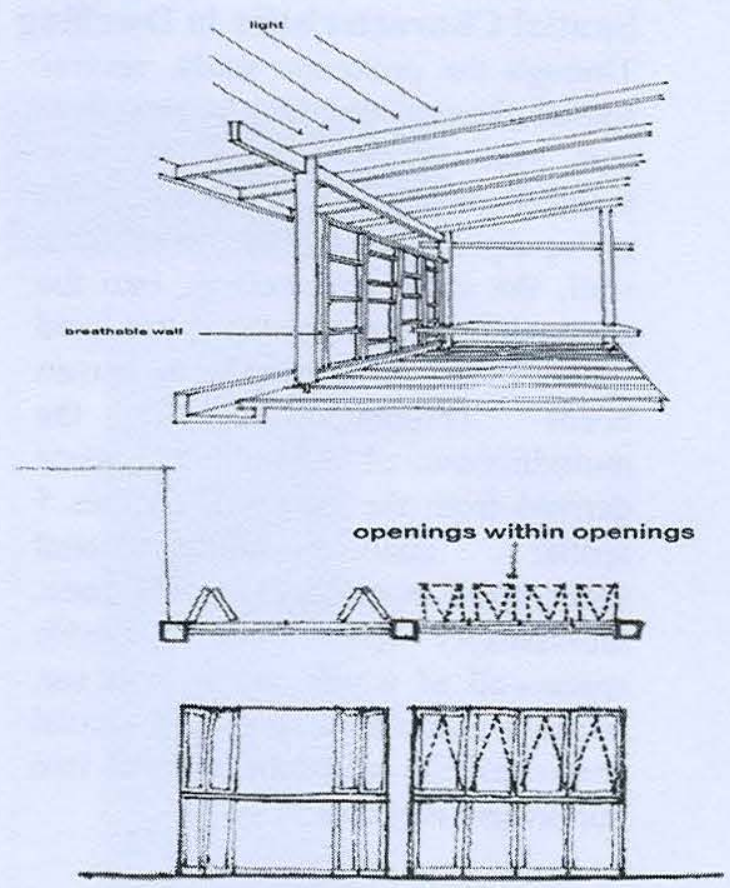

Figures 44-45. Openings within openings bring the multisensory world come to us; and thus welcome the touch of life to our proximity

\section{Growable space}

The space that is changeable, growable, and moveable in accordance with the rhythm of life, of time, constitutes another virtue of the multidimensional dwelling space. Given that "the past, the present, and the future give the house different dynamisms" 10 , this spatial characteristic allows life to take place and, as time goes by, take its root into the depth of the house. The "rootedness" of the dwellings and surrounding environment at Ban Khlong Lamsali unmistakably reveals an image of the continuous habitation of the large extended family. On these grounds, it is evident that life and place become one.

\footnotetext{
${ }^{10}$ Gaston Bachelard, The Poetics of Space (Boston: Beacon Press, 1969), p. 6.
} 

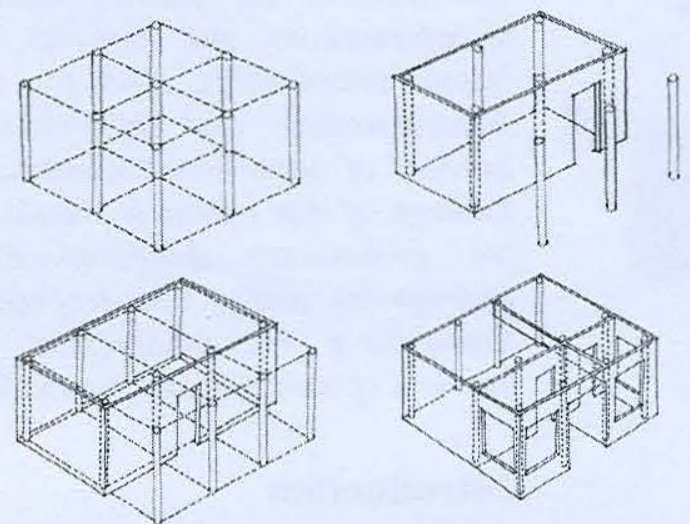

Figure 46. The trace and the incompleteness of structure allow the space to be changeable in relation to our growable life

\section{Epilogue}

Space is one of the structures which express our being in the world. Space is existential. Existence is spatial... Dwelling is the essential quality of existence.

Merleau-Ponty, quoted in Norberg-Schulz, 1971: 7, 16

As discussed throughout the course of the study, this research pays specifically attention to a dialectical relationship between the worthwhile use of space and the respectful use of place. Grounded in the context of Matriarchal society, the traditional Thai dwellings at Ban Khlong Lamsali unveil very rich spatial qualities: multifunctional space, space in space, dialogical space, multisensory space, and growable space. In this respect, to plant the "seed of our life" into the soil of the lived world implies an establishment of the meaning of the "house of life". To create the overarching concept of the house of life, these spatial qualities, by underscoring the climatic and cultural conditions, can bring out an understanding of Thai dwelling and contribute to the quality of life of those who reside in it.

\section{References:}

Bachelard, G. 1969. The Poetics of Space. Translated by Jolas, Maria. Boston: Beacon Press.

Fromm, E. 1990.The Sane Society. New York: An Owl Books.

Hall, E. T. 1969.The Hidden Dimension. New York: Anchor Press.

Hall, E. T. 1973. The Silent Language. New York: Anchor Press.

Norberg-Schulz, C. 1971.Existence, Space and Architecture. New York: Preager Publishers.

Norberg-Schulz, C. 1985. The Concept of Dwelling. New York: Rizzoli International Publications.

Norberg-Schulz, C. 2000.Architecture: Presence, Language, Place. Milan: Skira editore.

Relph, E. 1986.Place and Placelessness. $3^{\text {rd }}$ ed. London: Pion.

Tipsuda Patumanon. 1996.Prakottakarnsart Nai Sathapattayakam. [Phenomenology in Architecture] $2^{\text {nd }}$ ed. Bangkok: Chulalongkorn University Press.

Tipsuda Patumanon. 2004.Jittawittaya Sathapattayakam. [Architectural Psychology] Bangkok:

Chulalongkorn University Press.

Tuan, Yi-Fu. 1987.Space and Place. $4^{\text {th }}$ ed. Minnesota: University of Minnesota Press.

Waricha Wongphyat. 2004. The Proxemic Study in Dwelling: A Case Study of Traditional Thai Houses at Ban Khlong Lamsali. Chulalongkorn University: Thesis in Master of Architecture. 